\title{
Developing a Business Model to Help SMEs Implement an Effective Supply Chain using Unified Modeling Language
}

\author{
Omneya Kandil and Rasha Abd El Aziz \\ Business Information Systems Dept., CMT, Arab Academy for Science and Technology and Maritime \\ Transport, Alexandria, Egypt
}

Correspondence should be addressed to: Omneya Kandil: omneya.kandil@gmail.com

Received date: 7 November 2016; Accepted date: 6 January 2017; Published date : 17 March 2017

Academic Editor: Anas Al Bakri

Copyright @ 2017. Omneya Kandil and Rasha Abd El Aziz. Distributed under Creative Commons CCBY 4.0

\begin{abstract}
Purpose: The purpose of this paper is to develop a business model using analytical tools to generate quantitative evidence of the benefits of implementing an effective supply chain to assure the success of the organization in a highly competitive environment, limiting the scope to Egyptian SMEs.Design/methodology/approach: The study primarily uses a mixed methods approach; including semi-structured interview that was conducted to Egyptian SMEs and the data collected we reanalyzed using the Unified Modeling Language technique which provides an effective object oriented modeling tool that could be an appropriate analysis tool in the SMEs that operate in Egypt. Findings: The analysis showed how the supply chain was defined by Egyptian SMEs; it also mapped the current performance of the supply chain in order to understand the process's characteristics and capabilities. The result shows the obstacles and constrains facing the supply chain of the SME. Originality/value: Many SMEs in the Egyptian environment will be impacted as this research develops a model that suits them. The use of a Case Study approach with an object oriented tool, namely UML, makes this a thorough investigation that helps decision makers in Egyptian SMEs make better informed decisions.SMEs do not use the object oriented techniques in evaluating their problems, although it is very useful in analyzing the case study and modeling the current situation of the supply chain.
\end{abstract}

Keywords: Supply Chain, Small and Medium Enterprises (SMEs), Unified Modeling Language (UML).

Cite this Article as: Omneya Kandil and Rasha Abd El Aziz (2017), "Developing a Business Model to Help SMEs Implement an Effective Supply Chain using Unified Modeling Language" , Journal of Supply Chain and Customer Relationship Management, Vol. 2017 (2017), Article ID 291331,

กกI. 10 5171/2017 291231 


\section{Introduction}

Recent trends in the business world have forced companies to expand their activities into new regions where they can find qualified manpower, lower production costs, high availability of raw materials giving rise to wider and more complex supply chains bringing in new opportunities to leverage their competitive advantages (Zukerman, 2007). These changes require the implementation of new organizational models with different suppliers and partners who are responsible for an important part of the final product and consequently provide a service of excellence to satisfy customers (Hadaya and Pellerin, 2010).

Enterprises have to integrate information and communications technologies to improve internal processes within the enterprise and external processes with their business partners in the supply chain (Touboulic and Walker, 2015). Supply Chain Management (SCM) is a way to manage the total flows of a distribution channel from supplier's level to production, distribution and ultimately the end customer (Das et al., 2006). The supplier selection has become a very important matter for effective supply chain functions of any organization (Xia et al., 2008).Technologies support a wide range of needs in the supply chain interaction processes, including automation of a task, facilitation of collaboration process, and enabling the communication of information (Benton and McHenry, 2010).

The Unified Modeling Language (UML) is one of the object oriented analysis techniques; it was used because the data collected from the interviews were too much inter-related and complex so theyneeded a visual modeling language so that theycan be easily understood. UML has been identified as a way of providing a solution to the modeling bottleneck. Being the standard modeling language in software engineering, UML has received wide attention not only in the academic fields, but also in professional software development. The wide acceptance of UML makes it an ideal language to be used by organizations to build high quality models. UML can be used to model the current situation of the supply chain and find the problems faced by the SMEs in order to survive the current highly competitive environment (Rumbaugh et al., 2005).

\section{Literature Review}

Seeking a sustainable and defensible competitive advantage has become the priority for any manager competing in the international marketplace. The bases for success are abundant and the source of competitive advantage can be found in the firm's ability to differentiate itself from the competitors in the eyes of the customer. Another strategic direction to reach competitive advantage for a firm is to operate at a lower cost and therefore agreater profit (Morgan and Strong, 2003). Another key objective to any manager is to enhance the firm's supply chain responsiveness with respect to its customers (Melnyk et al., 2010).

\section{Supply Chain}

Any firm's success in a business market depends to a great extent on its relationships with customers and suppliers. In most industries, relationships are built up during considerable time. Tan (2001) argues that in a truly integrated supply chain, the final consumers pull the inventory through the value chain instead of the manufacturer pushing the items to the end-users, see figure 1 . The concept of supply chain management (SCM) is defined as "the integration of key business processes from end user through original suppliers that provides products, services and information that add value for customers and other stakeholders" (Dabic et al., 2015, Lambert and Cooper, 2000). Supply chain responsiveness is an important indicator of how well the supply chain strategy fulfills its objectives since it denotes the ability of the supply chain to adapt to changing customer needs and ultimately leads to elevated performance (Blome et al., 2013). 


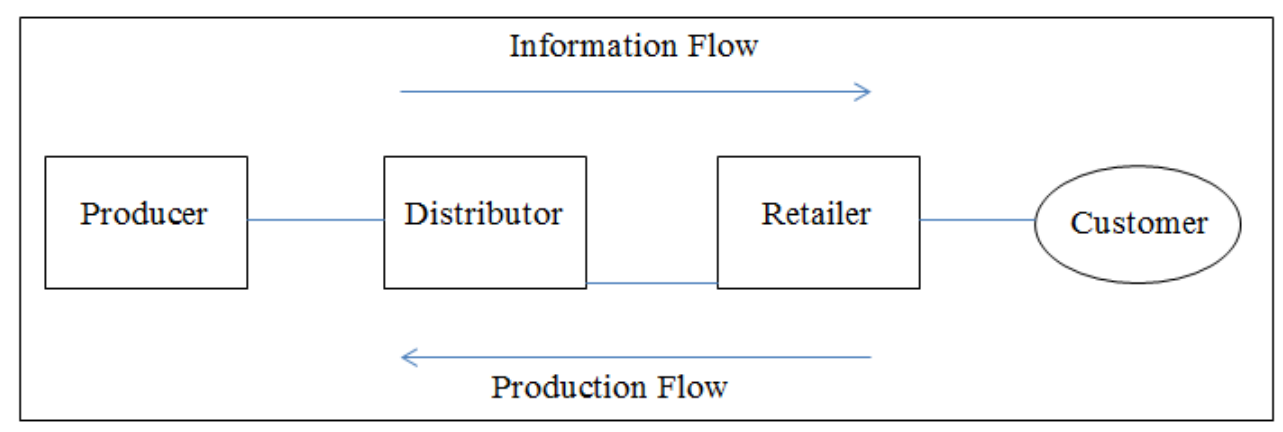

Figure 1: Supply Chain Flows

Nowadays the supply chains that have been developed are more complicated as the business has become more international (Anne and Walker, 2015). Supply chains can be simple structures of time and frequency distributions but in general they tend to be complex, owing to the presence of multiple autonomous organizations, functions and people set within a dynamic environment and this allowed the companies to provide customers with customized products (Qi et al., 2011).

As stated by Mitra and Bhardwaj (2010),the supply chain strategy should support the firm's business strategy and enhance the firm's responsiveness and performance in the marketplace. Firms can achieve two main competitive advantages. First, high integration among partners in supply chains can turn into more responsive firms to face volatile demand due to increased information visibility and operational knowledge (Kim, 2006). Secondly, highly integrated supply chain partners have the potential to decrease net costs of doing business and total delivered costs to customers (Swink et al., 2007). According to Arshinderand Deshmukh (2008), collaborative decision making in supply chain management helps to reduce information asymmetry, reduces inventory cost, improves the customer service and improves the efficiency of replenishment process.

\section{Small and Medium Enterprises}

Small and medium enterprises (SMEs) play significant role in the growth and development of any economy. The need for SMEs is consider as a means of ensuring self-independent, jobs creation, import substitution, effective and efficient utilization of local raw materials and participation to the economic development (Ong et al., 2012). Small and medium enterprises (SMEs) are playing significant contribution in the economic development, social uplifting and political stability of every country. SMEs are diverse in nature as they can be established for any kind of business activities in urban or rural areas. It can be considered as a back bone of national economy (Radam et al., 2008).

According to Floyd and McManus (2005), small firms in particular are traditionally considered to be more flexible in terms of changing their processes. The additional advantage that small enterprises have over large firms is the ability to respond quickly to the changing consumers' needs by being able to address the request for greater variety better. Furthermore, Deros et al (2006) claim that SMEs are more capable of offering personalized service which can also be perceived as an opportunity for building a competitive advantage. The additional characteristic mentioned by Floyd and McManus (2005) is the increased willingness to become more innovative and take risks. This claim stems from the fact that SMEs are often young companies with generally younger staff, 
and less constrained by rigid norms or codes of conduct.

According to Rezgui(2007), organizations are facing unpredicted challenges in a dynamic and constantly changing and complex environment (Abd El Aziz and Fady, 2013), such as, centralized power, employee empowerment, reduced complexity of interactions, streamlined communication, rapid decision making, clear vision, and the ability to consider every opinion. These challenges are expected to be particularly important for SMEs in particular, since SMEs have been acknowledged to be unique in nature (Parker andCastleman, 2009).

Although therole of SMEs is considered as the backbone of the economy(Radam et al., 2008), they face commonproblems in order to take competitive advantage. According to the available resources, more than $50 \%$ of SMEs collapsed within the first five years of operation. SMEs are facing serious issues and plenty of obstacles to stay as competitive enterprises in market (Omar et al., 2010).

According to Muhammad et al., (2010) the SMEs should mainly focus onovercoming the challenges facing SMEs in a globalized environment, which include recession, barrierfrom global sourcing, low productivity, lack of managerialskills, and difficulty of financing, and heavy regulatory burden. Muhammad et al.(2010) identified the main problems faced by SMEswhich could be the lack of knowledge regarding marketingtechniques, branding, customer loyalty and also lack of goodcontacts with other local and international enterprises.

The situation in Egypt is not different than the other countries; SMEs in Egyptare also expected to be a leader for economic and social development, through theirvital roles in increasing economic diversification, in creating job opportunities forcitizens (Hussien and Abd El Aziz, 2013). Omar et al. (2009) claimed that the SME sector playsa key role in the country's development especially in terms of self-employmentopportunities; leadership is the foundation of success for any businessestablishment. Inspiring leadership can identify challenges ahead and draw up plans to face them (Abd El Aziz, 2012).

SMEs are faced with many problems including heavy costs of compliance according totheir size, insufficient working supports and the difficulty to acquire finance. Additional,challenges are business development services, namely services related toentrepreneurship, lack of business training, marketing, technology development andinformation systems are underdeveloped and adequate to provide available information (Amer et al., 2014). At the same time, the institutions and associations supportingSMEs are poor, fragmented and uncoordinated partly due to lack of clear guidance andpolicy for the development of the sector (Abd El Aziz, 2009). It also has been observed that SMEs have social barriers which are the main obstacles to achieve the competitive advantage and consequently many SMEs lose out in terms of opportunities (Alam et al., 2011).

\section{Methodology}

In this section, the methodology that has been used in this research paper will be discussed.The data have been collected through the use of semi-structured interviews and direct observations tofive Egyptian SMEs that import clothes accessories from abroad. The interviewees were the key decision makers in these companies, such as, the owner, the import manager, the financial manager, the purchasing department manager, the warehouse supervisor, and the customer relationship manager. The interview questions were as follows;

1. What are you importing? And from where do you import the products?

2. How many containers do you order each year? 
3. How much inventory do you stock? And what is your replenishment plan?

4. Where and how do you store your stock?

5. How do you save your received products data?

6. How do you order your products?

7. What are the means of transportation that are used by your company to move the products from the supplier to you and from your warehouses to the customers?

8. How does your supply chain operate?

When the research has started, multiple companies that work in the same field have been visited and some of them were interviewed and it was found that the importing process is similar in all the companies and that these companies face the same problems and challenges, So a Representative Sampling was applied; which means that it can be assumed that the results of the evaluation are generalizable or applicable to the greater population (Adèr and Mellenbergh, 2014), so ElShamy Company was chosen to conduct this research on. ElShamy Companyis an Egyptian SMEthat imports clothes accessories.

The research was conducted on an SME in order to find a solution to the challenges that are faced by the SMEs as mentioned in the previous section in order for them to remain competitive in the Egyptian economy.This research is an explanatory research as it analyzes the current situation of the supply chain of ElShamyCompany using the Unified Modeling Language (UML). The data collected from the interviews and observations were complex and interrelated, so theyneeded a visual modeling language, such as UML, which allows the supply chain process to be visualized in multiple graphical models, so that it can be easily understood. It also will be used to produce several models which indicate increasing levels of detail.

\section{Analyzing the Supply Chain using Object Oriented Technique}

In this section the current supply chain of ElShamy Company, an SME that works in the trading process is analyzed using the Unified Modeling Language from the data that weregiven in the interview. The chapter starts by defining the UML diagram; starting with the use case diagram and the use case statements, followed by the class diagram and Class, Responsibilities, and Collaborators cards (CRC), followed by the collaboration diagram, sequence diagram, the activity diagram, and the state chart diagram.

The Unified Modeling Language (UML) is an object oriented technique that is used to analyze the data given in the interviews and make themclear and understandable in order for the SME to survive the current highly competitive environment. UML is a language used for specifying, visualizing, constructing, and documenting the artifacts of software systems, as well as for business modeling and other non-software systems. UML has two main diagram focus structural diagrams and behavioral diagrams. Structural diagrams are used to describe the relationships between different objects including class diagram. While the behavioral diagrams are used to describe the interactions between the system actors and the system itself; it includes use case diagrams, sequence diagrams, collaboration diagrams, activity diagrams, and statechart diagrams. It was developed by Grady Booch, James Rumbaugh, and IvarJacsobson (Bennett et al., 2011).

\section{UML Diagram Types}

There are several types of UML diagrams:

- Use-case Diagram; it shows actors, use-cases, and the relationships between them.

- Class Diagram; it shows relationships between classes and pertinent information about classes themselves. 
- Interaction Diagrams; Show an interaction between a group of collaborating objects. There are two types of interaction diagrams which are; collaboration diagram and sequence diagram

- $\quad$ State Diagram; describes behavior of instances of a class in terms of states, stimuli, and transitions.

- $\quad$ Activity Diagram; it is very similar to a flowchart as it shows actions and decision points, but with the ability to accommodate concurrency.

\section{Use Case Diagram}

Use case diagram is one of the UML diagrams that are used to represent the functionality of the system. It shows the functionality that the system will provide and the users who will communicate with the system to use that functionality.

The use case diagrams provide interactions between roles known as actors and system to achieve a certain goal. The role of use cases is required and observed at the analysis phase of modeling and system designing and it provides obvious benefits at this part of modeling the systems. (Perry, 2006).

\section{Use Case of ElShamy Company}

In figure (2), the use case of the supply chain of ElShamy Company is developed from the data given in the interview; it explains the current performance of thesupply chain, where the company develops its purchase request and sends it to the purchasing and the financial departments. When the two departments approve the purchase request, they send to the suppliers a request for quotations, and then the suppliers send their quotations to the company, then the company evaluates the respondent suppliers and their product qualities.

After choosing one of the suppliers, they start to negotiate with him and after these negotiations are finalized a contract will be issued and signed and the purchase request will be transformed to the purchase order, the company chooses the shipping method of the purchased products, either by direct shipping from the supplier or by a freight forwarding company, then the products are shipped. When the products are delivered to Egypt, the company inspects its received products and then adds them to its warehouses. 


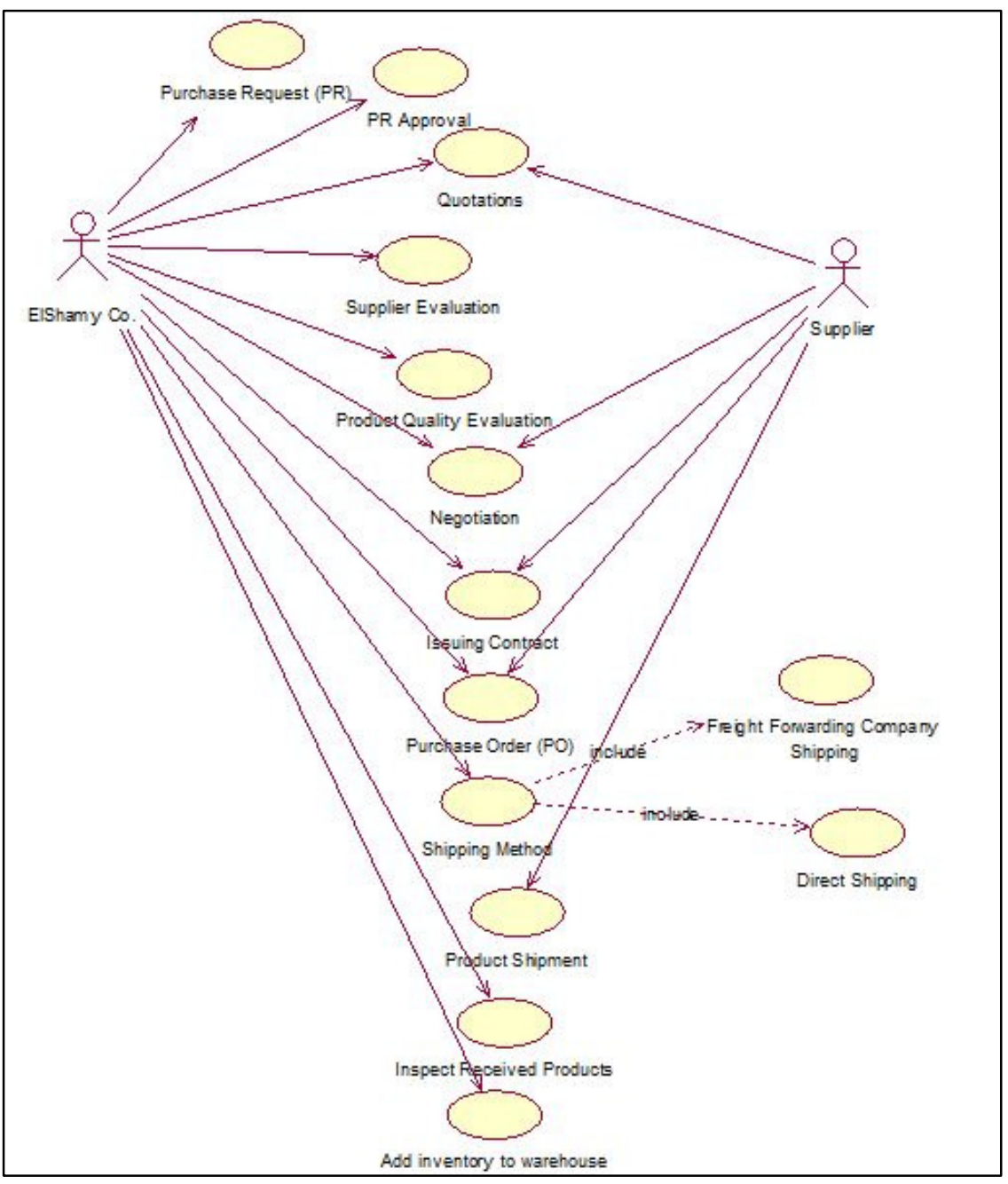

Figure 2: Use Case of the Supply Chain of El Shamy Company

\section{Use Case Statements}

Use case statement provides a detailed description of each use case. It includes the use case name, its primary and secondary actors, its description, what triggers the use case, its precondition, its post condition, its success scenario and its abort scenario. 
Table 1: Use Cases and the actors performing them

\begin{tabular}{|l|l|l|}
\hline Use Case ID & \multicolumn{1}{|c|}{ Use Case Name } & \multicolumn{1}{c|}{ Actors } \\
\hline $\mathbf{1}$ & Purchase Request (PR) & ElShamy Co. \\
\hline $\mathbf{2}$ & PR Approval & ElShamy Co. \\
\hline $\mathbf{3}$ & Quotations & ElShamy Co., Supplier \\
\hline $\mathbf{4}$ & Supplier Evaluation & ElShamy Co. \\
\hline $\mathbf{5}$ & Product Quality Evaluation & ElShamy Co. \\
\hline $\mathbf{6}$ & Negotiation & ElShamy Co., Supplier \\
\hline $\mathbf{7}$ & Issuing Contract & ElShamy Co., Supplier \\
\hline $\mathbf{8}$ & Purchase Order (PO) & ElShamy Co., Supplier \\
\hline $\mathbf{9}$ & Shipping Method & ElShamy Co. \\
\hline $\mathbf{9 . 1}$ & Freight Forwarding Company Shipping & ElShamy Co. \\
\hline $\mathbf{9 . 2}$ & Direct Shipping & ElShamy Co. \\
\hline $\mathbf{1 0}$ & Product Shipment & Supplier \\
\hline $\mathbf{1 1}$ & Inspect Received Products & ElShamy Co. \\
\hline $\mathbf{1 2}$ & Add Inventory to Warehouse & ElShamy Co. \\
\hline
\end{tabular}

Table 2: Use Case 1

\begin{tabular}{|l|l|}
\hline Use Case ID & 1 \\
\hline Use Case Name & Purchase Request (PR) \\
\hline Primary Actor & ElShamy Co. \\
\hline Secondary Actor & None \\
\hline Description & The company develops its purchase request. \\
\hline Trigger & The company decides to purchase new products. \\
\hline Pre-Condition & The company needed to purchase some products. \\
\hline Post- Condition & None \\
\hline Success Scenario & The purchase request is developed. \\
\hline Abort Scenario & The purchase request is not developed. \\
\hline
\end{tabular}


Table3: Use Case 2

\begin{tabular}{|l|l|}
\hline Use Case ID & 2 \\
\hline Use Case Name & PR Approval \\
\hline Primary Actor & ElShamy Co. \\
\hline Secondary Actor & None \\
\hline Description & $\begin{array}{l}\text { The Company's purchase and financial department approves the } \\
\text { purchase request. }\end{array}$ \\
\hline Trigger & The company develops a purchase request. \\
\hline Pre-Condition & The purchase request is developed. \\
\hline Post- Condition & None \\
\hline Success Scenario & The purchase request is approved. \\
\hline Abort Scenario & The purchase request is not approved. \\
\hline
\end{tabular}

Table 4: Use Case 3

\begin{tabular}{|l|l|}
\hline Use Case ID & 3 \\
\hline Use Case Name & Quotations \\
\hline Primary Actor & ElShamy Co. \\
\hline Secondary Actor & Supplier \\
\hline Description & $\begin{array}{l}\text { The company sends a request for quotation and the suppliers respond } \\
\text { by sending their quotations. }\end{array}$ \\
\hline Trigger & The company approves the purchase request. \\
\hline Pre-Condition & The purchase request is approved. \\
\hline Post- Condition & The company accepts one of the received quotations. \\
\hline Success Scenario & $\begin{array}{l}\text { The company sends a request for quotation and the suppliers send } \\
\text { their quotations }\end{array}$ \\
\hline Abort Scenario & $\begin{array}{l}\text { The company sends a request for quotation and the suppliers don't } \\
\text { send their quotations. }\end{array}$ \\
\hline
\end{tabular}

Table 5: Use Case 4

\begin{tabular}{|l|l|}
\hline Use Case ID & 4 \\
\hline Use Case Name & Supplier Evaluation \\
\hline Primary Actor & ElShamy Co. \\
\hline Secondary Actor & None \\
\hline Description & $\begin{array}{l}\text { The company evaluates the supplier according to some specified } \\
\text { criteria in order to proceed in the purchasing process. }\end{array}$ \\
\hline
\end{tabular}




\begin{tabular}{|l|l|}
\hline Trigger & The company accepts one of the received quotations. \\
\hline Pre-Condition & $\begin{array}{l}\text { The company sends a request for quotation and the suppliers send } \\
\text { their quotations and the company chooses one of these quotations. }\end{array}$ \\
\hline Post- Condition & None \\
\hline Success Scenario & The supplier is evaluated as a good supplier. \\
\hline Abort Scenario & The supplier is evaluated as a bad supplier. \\
\hline
\end{tabular}

Table 6: Use Case 5

\begin{tabular}{|l|l|}
\hline Use Case ID & 5 \\
\hline Use Case Name & Product Quality Evaluation \\
\hline Primary Actor & ElShamy Co. \\
\hline Secondary Actor & None \\
\hline Description & The products qualities that are sent in the quotations are evaluated. \\
\hline Trigger & $\begin{array}{l}\text { One of the quotations is accepted and its supplier is evaluated as a } \\
\text { good supplier. }\end{array}$ \\
\hline Pre-Condition & The supplier is evaluated as a good supplier. \\
\hline Post- Condition & None \\
\hline Success Scenario & The product qualities are evaluated as a good product quality. \\
\hline Abort Scenario & The product qualities are evaluated as a bad product quality. \\
\hline
\end{tabular}

Table7: Use Case 6

\begin{tabular}{|c|c|}
\hline Use Case ID & 6 \\
\hline Use Case Name & Negotiation \\
\hline Primary Actor & ElShamy Co. \\
\hline Secondary Actor & Supplier \\
\hline Description & $\begin{array}{l}\text { The company and the supplier start their negotiations to settle down } \\
\text { the prices, the payment terms, and the shipping date. }\end{array}$ \\
\hline Trigger & $\begin{array}{l}\text { The Supplier is evaluated as a good supplier and the qualities of the } \\
\text { products are accepted by the company. }\end{array}$ \\
\hline Pre-Condition & The products qualities are accepted by the company. \\
\hline Post- Condition & $\begin{array}{l}\text { The company and the supplier reach an agreement and finalize their } \\
\text { negotiations. }\end{array}$ \\
\hline Success Scenario & Negotiations are finalized. \\
\hline Abort Scenario & Negotiations are not finalized. \\
\hline
\end{tabular}


Table 8: Use Case 7

\begin{tabular}{|l|l|}
\hline Use Case ID & 7 \\
\hline Use Case Name & Issuing Contract \\
\hline Primary Actor & ElShamy Co. \\
\hline Secondary Actor & Supplier \\
\hline Description & The company and the supplier issue a contract and sign it. \\
\hline Trigger & The company and the supplier finalize the negotiations. \\
\hline Pre-Condition & The negotiations are finalized. \\
\hline Post- Condition & Contract is signed by both parties; the company and the supplier. \\
\hline Success Scenario & The contract is signed by both parties. \\
\hline Abort Scenario & The contract is not signed by both parties. \\
\hline
\end{tabular}

Table 9: Use Case 8

\begin{tabular}{|l|l|}
\hline Use Case ID & 8 \\
\hline Use Case Name & Purchase Order (PO) \\
\hline Primary Actor & ElShamy Co. \\
\hline Secondary Actor & Supplier \\
\hline Description & $\begin{array}{l}\text { The purchase request developed by the company is turned to a } \\
\text { purchased order. }\end{array}$ \\
\hline Trigger & The company and the supplier agree to a contract and sign it. \\
\hline Pre-Condition & The contract is signed by the company and the supplier. \\
\hline Post- Condition & None \\
\hline Success Scenario & $\begin{array}{l}\text { The purchase request is transformed into a purchase order directly } \\
\text { without any additional competitive bidding. }\end{array}$ \\
\hline Abort Scenario & $\begin{array}{l}\text { The purchase request is not transformed into a purchase order } \\
\text { directly without any additional competitive bidding. }\end{array}$ \\
\hline
\end{tabular}


Table 10: Use Case 9

\begin{tabular}{|l|l|}
\hline Use Case ID & 9 \\
\hline Use Case Name & Shipping Method \\
\hline Primary Actor & ElShamy Co. \\
\hline Secondary Actor & None \\
\hline Description & $\begin{array}{l}\text { The company chooses the shipping method that it prefers in delivering } \\
\text { the purchased products. }\end{array}$ \\
\hline Trigger & The purchase request is transformed into a purchase order. \\
\hline Pre-Condition & $\begin{array}{l}\text { The negotiations are finalized and the contract is signed and the } \\
\text { purchase request is transformed into a purchase order. }\end{array}$ \\
\hline Post- Condition & $\begin{array}{l}\text { The company should choose one of the two methods which are; the } \\
\text { freight forwarding shipping or the direct shipping. }\end{array}$ \\
\hline Success Scenario & The company chooses its shipping method. \\
\hline Abort Scenario & The company does not choose its shipping method. \\
\hline
\end{tabular}

Table 11: Use Case 9.1

\begin{tabular}{|c|c|}
\hline Use Case ID & 9.1 \\
\hline Use Case Name & Freight Forwarding Company Shipping \\
\hline Primary Actor & ElShamy Co. \\
\hline Secondary Actor & None \\
\hline Description & $\begin{array}{l}\text { The company chooses the freight forwarding method; the company } \\
\text { then should contact the freight forwarding company and send their } \\
\text { purchase order information in order for the freight forwarding } \\
\text { company to deliver the purchased products. }\end{array}$ \\
\hline Trigger & The company chooses the freight forwarding method. \\
\hline Pre-Condition & $\begin{array}{l}\text { The company chooses the freight forwarding method as the shipping } \\
\text { method to deliver the purchased products. }\end{array}$ \\
\hline Post- Condition & $\begin{array}{l}\text { The company and the freight forwarding company reach an agreement } \\
\text { and the freight forwarding company accepts to deliver the purchased } \\
\text { products. }\end{array}$ \\
\hline Success Scenario & $\begin{array}{l}\text { The freight forwarding company accepts to deliver the purchased } \\
\text { products. }\end{array}$ \\
\hline Abort Scenario & $\begin{array}{l}\text { The freight forwarding company does not accept to deliver the } \\
\text { purchased products. }\end{array}$ \\
\hline
\end{tabular}


Table 12: Use Case 9.2

\begin{tabular}{|l|l|}
\hline Use Case ID & 9.2 \\
\hline Use Case Name & Direct Shipping \\
\hline Primary Actor & ElShamy Co. \\
\hline Secondary Actor & None \\
\hline Description & $\begin{array}{l}\text { The company chooses the direct shipping method and the supplier } \\
\text { accepts to deliver the purchased products. }\end{array}$ \\
\hline Trigger & The company chooses the direct shipping method. \\
\hline Pre-Condition & $\begin{array}{l}\text { The company chooses the direct shipping method as the shipping } \\
\text { method to deliver the purchased products. }\end{array}$ \\
\hline Post- Condition & $\begin{array}{l}\text { The company and the supplier reach an agreement and the supplier } \\
\text { accepts to deliver the purchased products. }\end{array}$ \\
\hline Success Scenario & The supplier accepts to deliver the purchased products. \\
\hline Abort Scenario & The supplier does not accept to deliver the purchased products. \\
\hline
\end{tabular}

Table 13: Use Case 10

\begin{tabular}{|l|l|}
\hline Use Case ID & 10 \\
\hline Use Case Name & Product Shipment \\
\hline Primary Actor & Supplier \\
\hline Secondary Actor & None \\
\hline Description & The purchased products are shipped. \\
\hline Trigger & $\begin{array}{l}\text { The company chooses the shipping method that it prefers in delivering } \\
\text { the purchased products. }\end{array}$ \\
\hline Pre-Condition & $\begin{array}{l}\text { The company chooses the shipping method and the other party agrees } \\
\text { to deliver the purchased products. }\end{array}$ \\
\hline Post- Condition & None \\
\hline Success Scenario & The purchased products are shipped. \\
\hline Abort Scenario & The purchased products are not shipped. \\
\hline
\end{tabular}


Table 14: Use Case 11

\begin{tabular}{|c|c|}
\hline Use Case ID & 11 \\
\hline Use Case Name & Inspect Received Products \\
\hline Primary Actor & ElShamy Co. \\
\hline Secondary Actor & None \\
\hline Description & $\begin{array}{l}\text { The received products are inspected in order to ensure that the } \\
\text { received products are with the same quantity and quality specified in } \\
\text { the purchase order. }\end{array}$ \\
\hline Trigger & The purchased products are shipped. \\
\hline Pre-Condition & The purchased products are shipped and arrive to Egypt. \\
\hline Post- Condition & None \\
\hline Success Scenario & $\begin{array}{l}\text { The received products are with the same quantity and quality } \\
\text { specified in the purchase order. }\end{array}$ \\
\hline Abort Scenario & $\begin{array}{l}\text { The received products are not with the same quantity and quality } \\
\text { specified in the purchase order. }\end{array}$ \\
\hline
\end{tabular}

Table 15: Use Case 12

\begin{tabular}{|c|c|}
\hline Use Case ID & 12 \\
\hline Use Case Name & Add Inventory to Warehouse \\
\hline Primary Actor & ElShamy Co. \\
\hline Secondary Actor & None \\
\hline Description & $\begin{array}{l}\text { The purchased products are then transported to the company's } \\
\text { warehouses. }\end{array}$ \\
\hline Trigger & The products are shipped and inspected. \\
\hline Pre-Condition & $\begin{array}{l}\text { The received products are with the same quantity and quality specified } \\
\text { in the purchase order. }\end{array}$ \\
\hline Post- Condition & None \\
\hline Success Scenario & $\begin{array}{l}\text { The purchased products are transported and organized in the } \\
\text { company's warehouses. }\end{array}$ \\
\hline Abort Scenario & $\begin{array}{l}\text { The purchased products are not transported and organized in the } \\
\text { company's warehouses. }\end{array}$ \\
\hline
\end{tabular}




\section{Class Diagram}

Class diagram, is the most important in object-oriented modeling of business concepts. The use case diagram shows only the viewpoint of system/actors relations. The class diagram checks the internal structure and gives an abstract representation of objects. The principal elements of this static view are classes and their relationships, such as associations, generalization, aggregation and other types of dependencies. Each class in the class diagram includes the class name, attributes and its operations (Sarma and Mall, 2007)

Class Diagram of EL Shamy Company

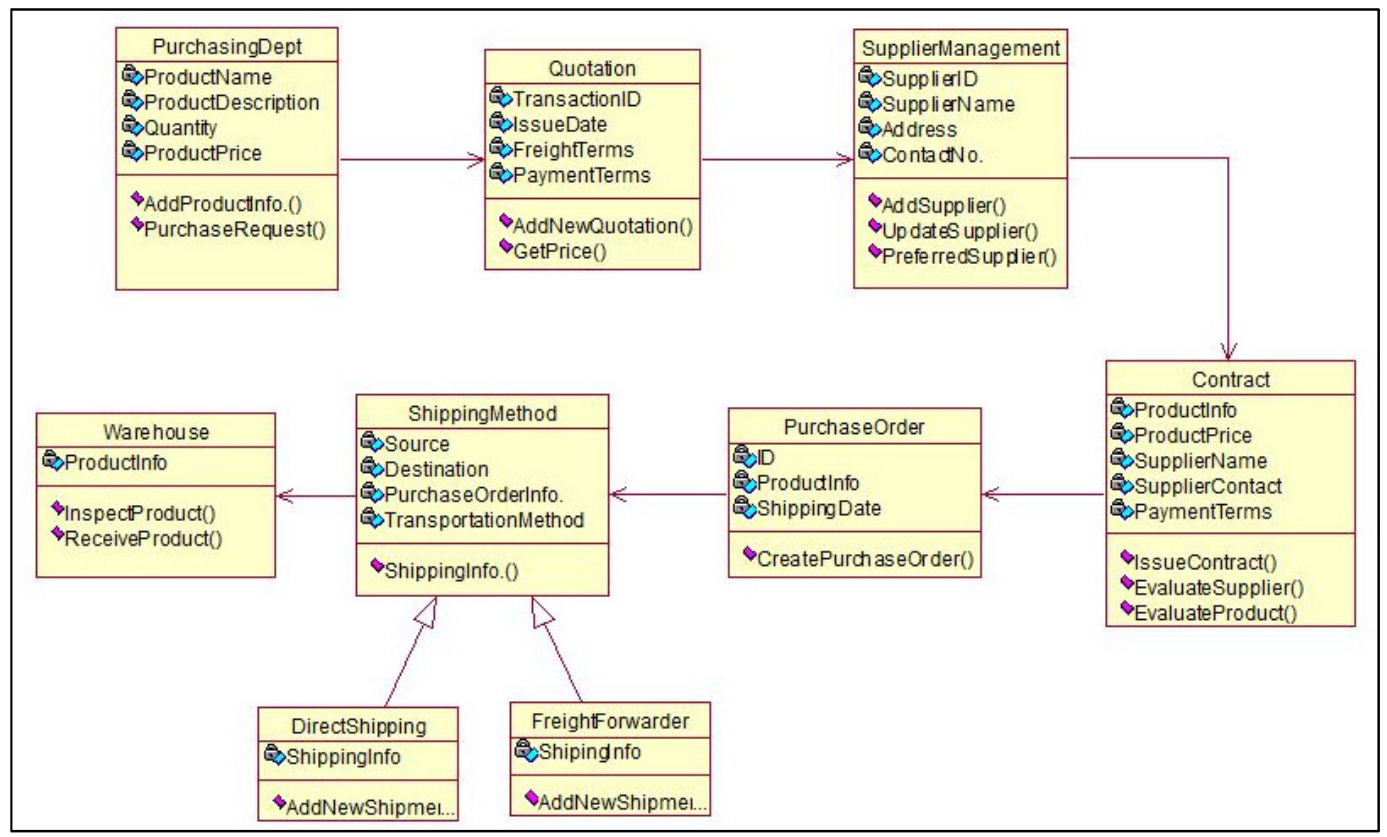

Figure 3: Class Diagram of the Supply Chain of ElShamy Company

Class Responsibility Collaborator (CRC) Cards

CRC cards are used to provide a detailed document that includes the properties of each class and represent its responsibilities and the collaborators that show the relationships between the classes of the supply chain shown in Figure (3). 
Table 16: CRC of Purchasing Department

\section{Purchasing Dept}

- The company collects the product information, such as the product name, description, the quantity needed, and the last purchased price.

- The company adds the collected product information to the purchase request.

Table 17: CRC of Quotation

\section{Quotation}

- The company receives quotations from different suppliers and adds them to be compared in order to choose the best quotation received.

Quotation

- PurchasingDept

- Supplier Management

Table 18: CRC of Supplier Management

\section{Supplier Management}

- The company adds the information of each supplier and updates itregularly.

- The suppliers the company deals with often are added to the preferred suppliers.

- Quotation

- $\quad$ Contract

\section{Table 19: CRC of Contract}

\section{Contract}

- The company evaluates the suppliers according to specified criteria.

- The company evaluates the quality of the products sent by the supplier.

- The company and the supplier issue the contract and sign it.
- Supplier Management

- Purchase Order 
Table 20: CRC of Purchase Order

\section{Purchase Order}

- The company collects the products information from the purchase request and the shipping date that the supplier can send the purchased products on, and creates the purchase order.
- Contract

- $\quad$ Shipping Method

Table 21: CRC of Shipping Method

\section{Shipping Method}

- The company chooses the shipping method that the products will be delivered by.

- The company adds the shipment information to the purchase order and sends it either to the supplier in case of direct shipping or to the freight forwarding company.
- $\quad$ Purchase Order

- $\quad$ Direct Shipping

- $\quad$ Freight Forwarder

- Warehouse

Table 22: CRC of Warehouse

\section{Warehouse}

- The company receives the products.

- The company inspects the received products.

- The company adds the received products to the warehouse.

\section{Sequence Diagram}

Sequence diagrams describe the interactions among classes in terms of an exchange of messages over time. An important characteristic of a sequence diagram is that time passes from top to bottom; the interaction starts near the top of the diagram and ends at the bottom.
The sequence diagram consists of a list of participants that are usually arranged in order of activation, messages sent to and received from participants are denoted by arrows and arranged along the vertical axis according to the time sent or received; messages represent the operations of the participants. The sequence diagram is used to represent the overall sequence of the activities or interactions in a use case (Sarma et al., 2007). 


\section{Sequence Diagram of EL Shamy Company}

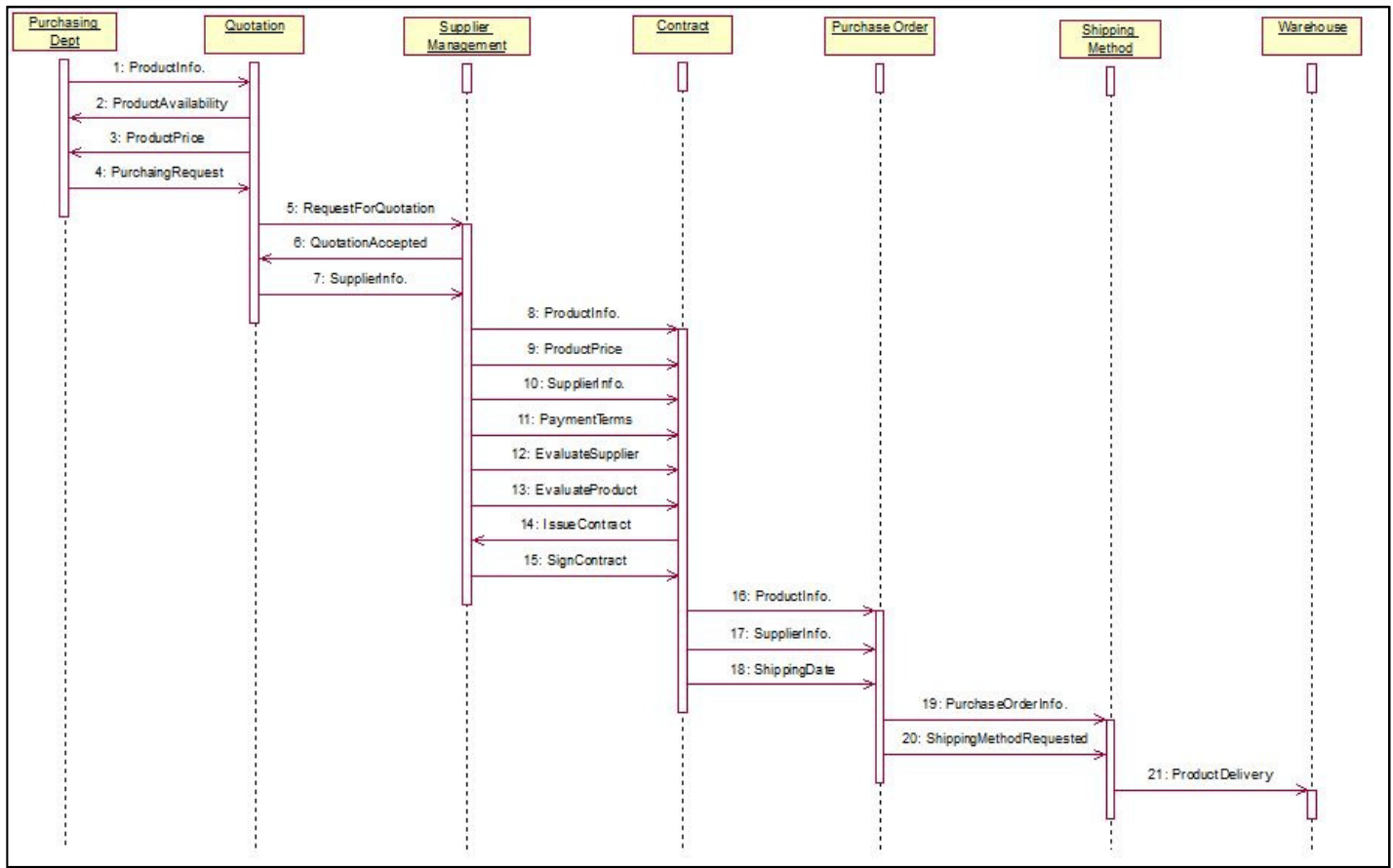

Figure 4: Sequence Diagram of the Supply Chain of ElShamy Company

\section{Collaboration Diagram}

A collaboration diagram is also called a communication diagram or an interaction diagram. It is an illustration of the relationships and interactions among software objects in the Unified Modeling Language (UML). A collaboration diagram describes the interactions among objects in terms of sequenced messages. Collaboration diagrams represent a combination of information taken from class, sequence, and use case diagrams describing both the static structure and the dynamic behavior of a system. Although collaboration diagram shows same information as sequence diagram but they differ in their focus as the collaboration diagram emphasizes the organization of objects while the sequence diagram emphasizes the time ordering of messages (Sarma and Mall, 2007). 


\section{Collaboration Diagram of EL Shamy Company}

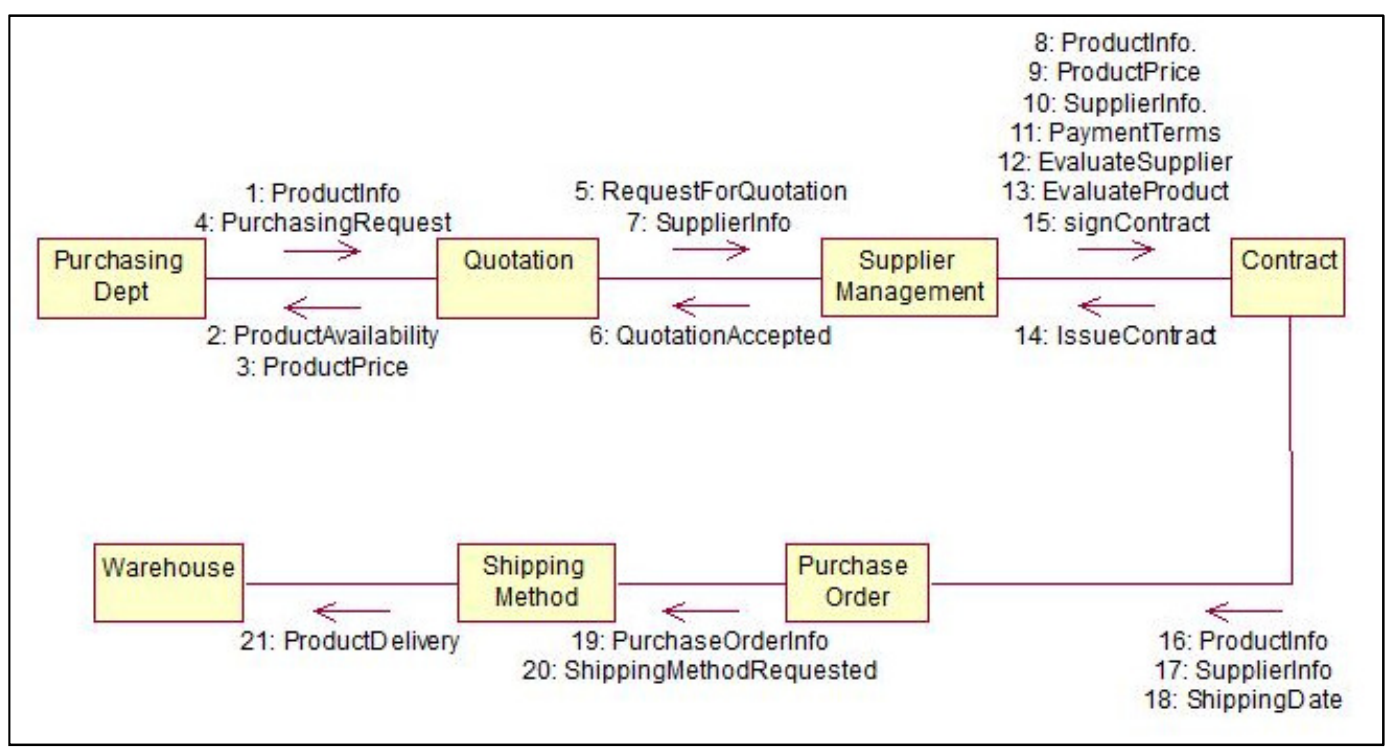

Figure 5: Collaboration Diagram of the Supply Chain of ElShamy Company

\section{Activity Diagram}

Activity diagram is basically like a flow chart to represent the flow form one activity to another activity. The activity can be described as an operation of the system, so the control flow is drawn from one operation to another. This flow can be sequential, branched or concurrent. The activityis drawn as a rectangle with rounded ends which represent an activity, an arrow represents an event, a diamond represents either a decision or a merge, and finally decisions have one arrow going into the diamond and several going out (Heinecke et al., 2010). 


\section{Activity Diagram of EL Shamy Company}

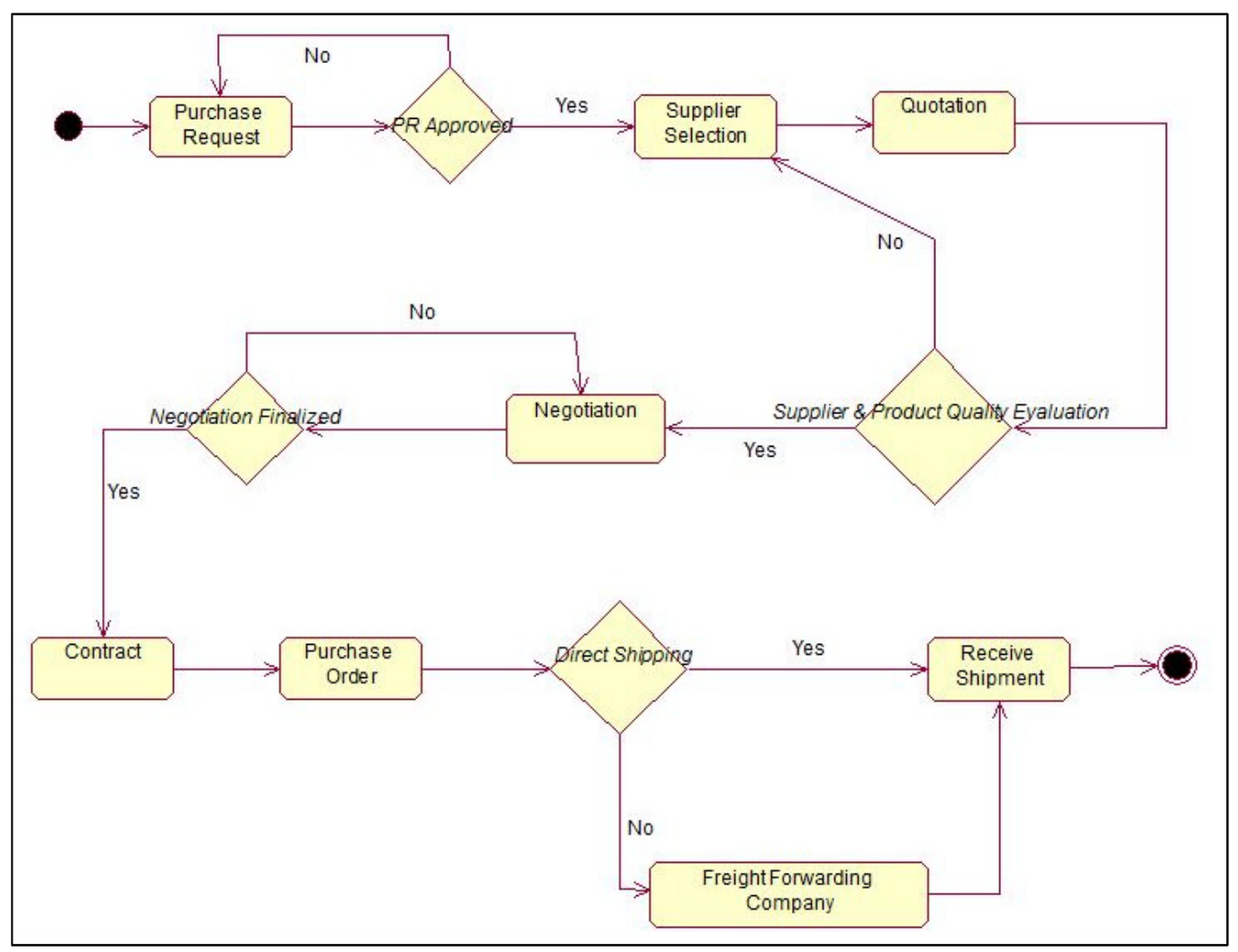

Figure 6: Activity Diagram of the Supply Chain of ElShamy Company

\section{Statechart Diagram}

It describes the behavior of entities capable of dynamic behavior by specifying its response to the events. A Statechart diagram describes a state machine which can be defined as a machine which has different states of an object and these states are controlled by external or internal events. They define different states of an object during its lifetime. And these states are changed by events. So Statechart diagrams are useful to model reactive systems. Reactive systems can be defined as a system that responds to external or internal events. Statechart diagram describes the flow of control from one state to another state. (Sarma and Mall, 2007). 


\section{Statechart Diagram of ELShamy Company}

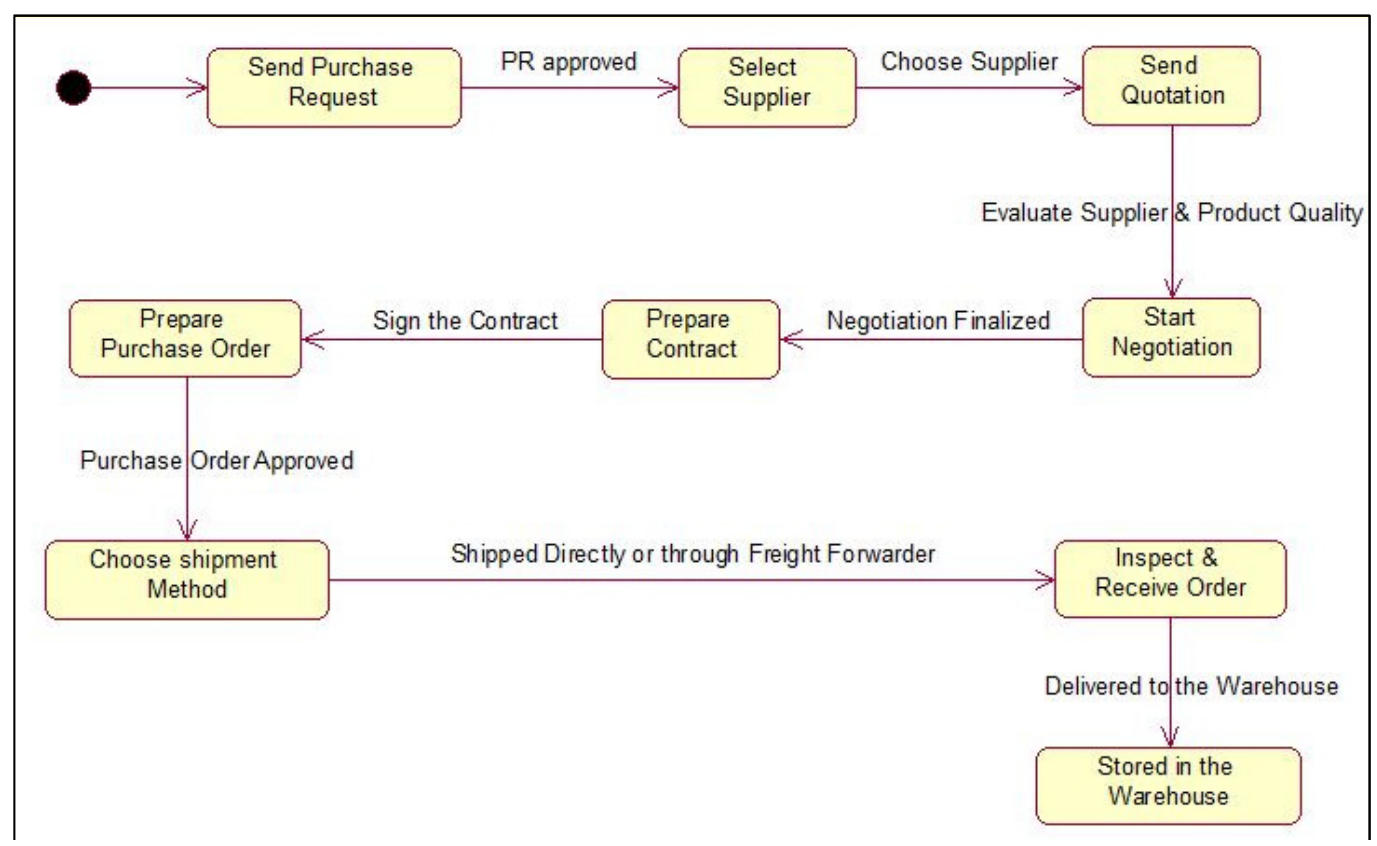

Figure 7: Statechart Diagram of the Supply Chain of ElShamy Company

\section{Conclusion}

An effective supply chain assures the success of the organization in a highly competitive environment. To upgrade their supply chain performance and competitiveness, organizations are seeking the ways to deal with suppliers. Supplier selection and relationship strategies have become part of a well-managed supply chain process and have a great impact on the competitiveness of the entire supply chain.

The contribution of SMEs to the economy of a country has been recognized in emerging countries and its effect can be seen in income growth, entrepreneurial training, and the creation of technological capability, greater flexibility in changing market circumstances, job creation, and lower wage inequality. However, SMEs have major challenges that face them, such as, challenges that are caused by their size and lack of market experience. Unified Modeling Language (UML) is a comprehensive modeling tool that was used to explore and evaluate the current performance of the supply chain of ElShamy Company, which is an SME that operates in Egypt, from the data given in the interviews.

As a result, it was discovered that ElShamy Company does not have enough records of the products stored in the warehouse, for example, the colors of the items stored and their quantities, which may lead to stealing them. It was also found that the supplier after shipping the products does not have any supervision on the products sent.

Finally, the research at hand provides a developed model that suits the Egyptian market, which was derived from the investigation using a mixed methods approach. Research methods used in this study include a review of literature, conducting semi-structured interviews with decision makers at SMEs' together with direct observations to the supply chain process of each company. Data collected wereanalyzed using the UML which provides an effective object oriented modeling tool that could be an appropriate 
analysis tool in the SMEs that operate in Egypt.

\section{References}

1. Abd El Aziz, R. (2009) ATM Location and Usage in Egypt: Social and Technical Perspectives, PhD Thesis, University of the West of England, Brisol, UK.

2. Abd El Aziz, R. (2012) ATM Usage: A Stakeholder Analysis the Egyptian Context, 14 March 2012, LAP LAMBERT Academic Publishing, ISBN-10: 384840835X, ISBN13: 978-3848408351

3. Abd El Aziz, R., and Fady, R., (2013), "Business Improvement using Organisational goals, Riva technique and EBusiness Development stages: A Case Study Approach", regular issue of the Journal of Enterprise Information Management, Emerald, Vol. 26, No. 5, pp. 577-595.

4. Adèr H.J, and MellenberghG.J, (2014), "Advising on research Methods: Selected topics", Johannes van Kessel Publisher, 2011, ISBN: 9079418137, 9789079418138.

5. AlamS., JaniM., Senik Z., and Domil A., (2011),"Assessing Barriers of Growth of Food Processing SMIs in Malaysia: A Factor Analysis", International Business Research, Vol. 4, No. 1, January 2011.

6. Amer S., Abd El Aziz R. and Hamza M., (2014), "Business Process Management in Small and Medium Enterprises: The Service Industry", International Journal of Advanced Research in Computer Science and Software Engineering, Vol. 8, No. 4, pp. 1096-1103, August 2014.

7. Anne T., Walker H., (2015), "Theories in sustainable supply chain management: a structured literature review", International Journal of Physical Distribution \& Logistics Management, Vol. 45, No. 1/2, pp. 16-42.

8. Arshinder, K.A. and Deshmukh, S.G., (2008), "Supply chain coordination: perspectives, empirical studies and research directions", International Journal of Production Economics, Vol. 115, pp. 31635.

9. Bennett S., Farmer R., and McRobb S., (2011),"Object-Oriented Systems Analysis and Design: Using UML", 4th Edition, ISBN: 0077125363, McGraw-Hill.

10. Benton W.C.J., and McHenry L.F., (2010), "Construction Purchasing and Supply Chain Management", McGraw-Hill, London.

11. Blome C., Schoenherr T. and Rexhausen D., (2013), "Antecedents and enablers of supply chain agility and its effect on performance: a dynamic capabilities perspective", International Journal of Production Research, Vol. 51, No. 4, pp. 1295-1318.

12. Dabic M., Loureiro M., Kiessling T., (2015),"Supply chain management as the key to a firm's strategy in the global marketplace: Trends and research agenda", International Journal of Physical Distribution \& Logistics Management, Vol. 45, No. 1/2, pp. 159-181.

13. Das A., Narasimhan R., and Talluri S., (2006), "Supplier integration - finding an optimal configuration", Journal of Operations Management, Vol. 24, pp. 56382.

14. Deros B., Yusof S., Salleh A., (2006), “A benchmarking implementation framework for automotive manufacturing SMEs", Benchmarking: Int. J., Vol. 13, pp. 396-430.

15. Floyd D., and McManus J., (2005), "The role of SMEs in improving the competitive position of the European Union", European Business Review, Vol. 17, No.2, pp. 144150.

16. Hadaya P., and Pellerin R., (2010), "Determinants of construction companies' use of web-based interorganizational information systems", Supply Chain Management: An International Journal, Vol. 15, No. 5, pp. 371-384.

17. Heinecke A., Brückmann T., Griebe T., Gruhn V., (2010), “Generating Test Plans for Acceptance Tests from UML Activity 
Diagrams", 17th IEEE International Conference and Workshops on Engineering of Computer-Based Systems, 2010.

18. Hussien, M., I. and Abd El Aziz, R (2013), 'Investigating E-Banking Service Quality in one of Egypt's Banks: A stakeholder Analysis', The TQM Journal, Emerald, Quality Improvement in East Africa, Vol. 25, No. 5, pp. $557-576$.

19. Kim S.W., (2006), "The effect of supply chain integration on the alignment between corporate competitive capability and supply chain operational capability", International Journal of Operations and Production Management, Vol. 26, No. 10,pp. 1084-107.

20. Lambert D., and CooperM., (2000) "Issues in supply chain management. Industrial Marketing Management"Vol. 29, pp. 65-83.

21. Melnyk S.A., Davis E.W., Spekman R.E., and Sandor J., (2010), "Outcome-driven supply chains", Sloan Management Review, Vol. 51, No. 2, pp. 33-38.

22. Mitra A., and Bhardwaj S., (2010), "Alignment of supply chain strategy with business strategy", IUP Journal of Supply Chain Management, Vol. 7, No. 3, pp. 49-65.

23. Morgan R.E.,and Strong C.A., (2003), "Business performance and dimensions of strategic orientation", Journal of Business Research, Vol. 56, pp. 163-176.

24. Muhammad M., Char A., Yasoa M., and Zakiah H., (2010),"Small and Medium Enterprises (SMEs) Competing in the Global Business Environment: A Case of Malaysia". International Business Research, Vol.3, No. 1.

25. Omar S., bt S., and Ismail M., (2010),"The Background and Challenges Faced by the Small Medium Enterprises. A Human Resource Development Perspective", International Journal of Business and Management, Vol.4, No.10.

26. Omar S., bt S. and Ismail, M. (2009), "The background and challenges faced by the small medium enterprises. A human resource development perspective", Journal of Business and Management, Vol. 4 No. 10, pp. 95-102.

27. Ong J.W., Ismail H., Yeap P.F., Emmanuel O.O. and Daniya A.A. (2012), "Malaysian small and medium enterprises: the fundamental problems and recommendations for improvement", Journal of Asia Entrepreneurship and Sustainability, Vol. 6, No. 1, pp. 95-102.

28. Parker C.M., andCastleman T., (2009), "Small firm e-business adoption: a critical analysis of theory", Journal of Enterprise Information Management 22, Vol. 1, No. 2, pp. 167-182.

29. Perry W.E., (2006), "Effective Methods for Software Testing", 3rd Edition, Wiley, 2006.

30. Qi Y., Zhao X. and SheuC., (2011), "The impact of competitive strategy and supply chain strategy on business performance: the role of environmental uncertainty", Decision Sciences, Vol. 42, No. 2, pp. 371389.

31. Radam A., Abu B.L. and AbdullahC.M, (2008),"Technical Efficiency of Small and Medium Enterprise in Malaysia: A Stochastic Frontier Production Model",International Journal of Economics and Management Vol. 2, No. 2.

32. Rezgui Y., (2007),"Exploring virtual team-working effectiveness in the construction sector". Interacting with Computers, Vol. 19, pp. 96-112.

33. Rumbaugh J., Jacobson I., and Booch G., (2005), "The Unified Modeling Language Reference Manual", 2nd edition.AddisonWesley, Reading, MA, 2005.

34. Sarma M., Kundu D., Mall R., (2007), "Automatic Test Case Generation from UML Sequence Diagrams", 15th International Conference on Advanced Computing and Communications, IEEE, 2007.

35. Sarma M., and Mall R., (2007), "System Testing using UML Models", 16th Asian Test Symposium, IEEE, 2007. 
36. Swink M., Narasimhan R., and Wang C., (2007), "Managing beyond the factory walls: effects of four types of strategic integration on manufacturing plant performance", Journal of Operations Management, Vol. 25, No. 1, pp. 148-64.
37. Tan K., (2001), "A framework of supply chain management literature", European Journal of Purchasing and Supply Management, Vol. 7, pp. 39-48.

38. Zukerman A., (2007), "Explosion of options in global supply chain integration", World Trade, April, pp. 42-6. 